\title{
BOD1L1 wt Allele
}

National Cancer Institute

\section{Source}

National Cancer Institute. BOD1L1 wt Allele. NCI Thesaurus. Code C150177.

Human BOD1L1 wild-type allele is located in the vicinity of 4p15.33 and is approximately $59 \mathrm{~kb}$ in leng th. This allele, which encodes biorientation of chromosomes in cell division protein 1 -like 1 protein, is involved in replication fork maintenance. 